\title{
Malignant Dermal Neoplasm
}

National Cancer Institute

\section{Source}

National Cancer Institute. Malignant Dermal Neoplasm. NCI Thesaurus. Code C4574.

A malignancy that affects the dermis. 